\title{
PKM KERAJINAN KERAMIK ANEKA PRODUK OLAHAN TANAH LIAT SIKU BALI HANDYCRAFT DI BALI
}

\section{*I Gusti Ayu Ratih Permata Dewi ${ }^{1}$, Putu Yudha Asteria Putri², I Gde Agung Wira Pertama $^{3}$}

\author{
1,2Program Studi Akuntansi, Fakultas Ekonomi dan Bisnis, Universitas Warmadewa
}

${ }^{3}$ Program Studi Manajemen, Fakultas Ekonomi dan Bisnis, Universitas Warmadewa

*Email: ratihpermatadewiiga@yahoo.com

\begin{abstract}
Craft is an object of human art that is related to hand skills. Besides having aesthetic value, the shape of the craft has economic value. One of the handicrafts in Bali is ceramics. These ceramics are usually used as souvenirs for tourists who come to Bali. The target audience of this community service program is the "Siku Bali Handycraft" located in Keramas Village, Blahbatuh District, Gianyar Regency, Bali Province. Siku Bali Handycraft is a partner owned by I Wayan Catur as well as a maker / craftsman of ceramic crafts. Mr. I Wayan Catur began to pioneer his work in 2009. He gained this expertise from generation to generation among his extended family. Ceramic crafts produced include incense holders, candle holders, oil kilns, flower vases, bottles for tea and coffee. The basic contribution of this program is to increase production capacity, increase marketing through online, improve the quality of human resources, increase turnover and company assets.
\end{abstract}

Keywords: Ceramic Crafts, Clay, Assistance

\begin{abstract}
ABSTRAK
Kerajinan merupakan suatu benda hasil karya seni manusia yang berkaitan dengan keterampilan tangan. Selain memiliki nilai estetis bentuk benda kerajinan tersebut memiliki nilai ekonomi. Salah satu kerajinan yang ada di Bali adalah kerajinan keramik. Kerajinan keramik ini biasanya digunakan sebagai oleh-oleh (souvenir) bagi wisatawan yang datang ke Bali. Khalayak sasaran dari program pengabdian masyarakan ini adalah "Siku Bali Handycraft" yang terletak di Desa Keramas Kecamatan Blahbatuh Kabupaten Gianyar Provinsi Bali. Siku Bali Handycraft merupakan mitra yang dimiliki oleh I Wayan Catur sekaligus sebagai pembuat/ pengrajin kerajinan keramik. Bapak I Wayan Catur mulai merintis karyanya pada tahun 2009. Beliau mendapatkan keahlian ini secara turun temurun diantara keluarga besarnya. Kerajinan keramik yang dihasilkan diantaranya tempat dupa, tempat lilin, tempat pembakaran minyak, vas bunga, botol untuk tempat teh dan kopi. Kontribusi dasar dari program ini adalah meningkatkan kapasitas produksi, peningkatan pemasaran melalui online, peningkatan kualitas SDM, peningkatan omset dan asset perusahaan.
\end{abstract}

Kata Kunci: Kerajinan Keramik, Tanah Liat, Pendampingan

\section{PENDAHULUAN}

Bangsa Indonesia sebagai wilayah tropis memiliki dasar kebudayaan agraris yang 
tersebar di seluruh daerah. Salah satu ciri kebudayaan bangsa Indonesia terletak pada kebiasaan para petani yang memanfaatkan bahan baku dari alam sekitarnya. Salah satu bahan baku yang dimanfaatkan adalah tanah liat. Indonesia yang kaya akan sumber daya alam mineral memiliki potensi besar dalam menghasilkan bahan baku untuk pembuatan produk-produk kriya. Salah satu potensi alam tersebut adalah tanah liat yang terdapat pada hampir seluruh wilayah Indonesia baik di Sumatera, Bangka, Belitung, Jawa, Kalimatan, Sulawesi, Bali, Nusa Tenggara, bahkan di Papua. Tanah liat yang dihasilkan pada setiap daerah memiliki bentuk, warna dan tingkat elastisitas yang berbeda, tergantung dari material pembentuknya ${ }^{1}$.

Salah satu kerajinan yang terbuat dari tanah liat dapat dijumpai di Bali adalah kerajinan keramik. Permintaan akan kerajinan keramik berasal dari penduduk lokal Bali dan wisatawan domistik. Pada awalnya kerajinan keramik ini dibuat untuk oleh-oleh khas Bali bagi wisatawan yang datang ke Bali. Namun, karena kerajinan keramik yang dibuat dapat digunakan untuk kehidupan sehari-hari, contohnya asbak, vas bunga, tempat dupa, tempat lilin dan lain sebagainya sehingga masyarakat lokal Bali tertarik juga untuk membelinya. Bentuk kerajinan keramik yang unik juga menggambarkan ciri khas Bali. Kerajinan keramik mampu menambah kesan mewah furniture yang ada di suatu ruangan. Keunikan dan keindahan kerajinan keramik inilah yang membuat kerajinan keramik ini banyak diminati oleh pelanggan dalam maupun luar negeri. Khalayak sasaran dari program pengabdian masyarakan ini adalah "Siku Bali Handycraft" yang terletak di Desa Keramas Kecamatan Blahbatuh Kabupaten Gianyar Provinsi Bali dengan jarak sekitar 18 km dari kota Denpasar. Berbagai jenis atau model kerajinan keramik yang dibuat mulai dari ukuran kecil sampai yang besar. Siku Bali Handycraft merupakan mitra yang dimiliki oleh I Wayan Catur sekaligus sebagai pembuat/ pengrajin kerajinan keramik ini. Bapak I Wayan Catur mulai merintis karyanya pada tahun 2009. Beliau mendapatkan keahlian ini secara turun temurun diantara keluarga besarnya. 

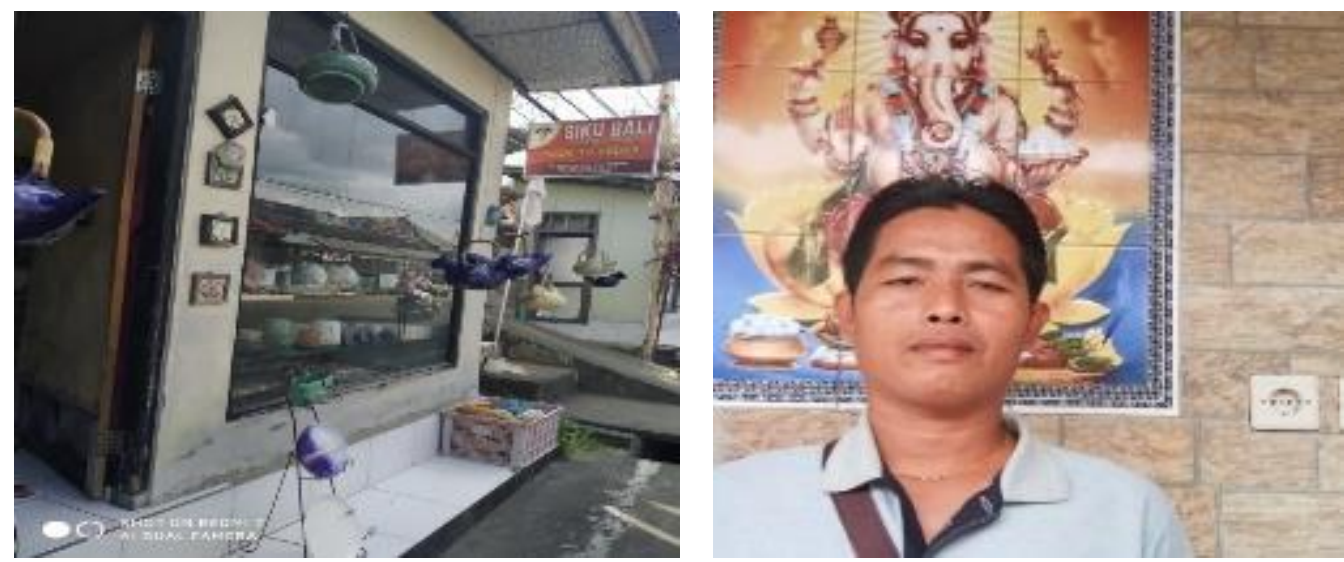

\section{Gambar 1. Profil I Wayan Catur dengan Siku Bali Handycraft}

Kerajinan keramik yang dibuat menggunakan bahan baku tanah liat. Tahapan proses kerajinan keramik dimulai dari pembentukan keramik dari tanah liat. Tanah liat dibentuk sesuai dengan apa yang diinginkan seperti bentuk tempat dupa, tempat lilin, tempat pembakaran minyak, vas bunga, botol untuk tempat teh dan kopi. Setelah proses pembentukan sudah selesai hasil dari kerajinan tanah liat lanjut ke proses pengeringan. Pengeringan berguna untuk menghilangkan air yang terjebak di dalamnya. Proses pengeringan yang paling baik dilakukan dengan memanfaatkan angin alam dan suhu ruangan atau penjemuran diluar ruangan memanfaatkan terik matahari. Proses selanjutnya adalah pembakaran, proses ini dilakukan supaya keramik yang semula rapuh menjadi padat, keras, dan kuat. Faktor-faktor yang mempengaruhi hasil pembakaran di antaranya suhu matang, atmosfer tungku, dan mineral yang terlibat. Bahan-bahan keramik mentah kemudian dimasukkan ke dalam tungku pembakaran lalu dibakar memakai suhu sekitar 700-1.000 derajat celcius. Selanjutnya proses pengglasiran. Proses pengglasiran adalah untuk melindungi keramik, memperkuat struktur, dan memperindah tampilannya. Penerapan bahan glasir ini dapat dilakukan dengan cara dicelup, disemprot, dituang, atau dioles dengan kuas ke permukaan keramik secara merata. Fungsi pengglasiran pada keramik adalah untuk menambah keindahan, supaya lebih kedap air, dan menambahkan efek-efek tertentu sesuai keinginan ${ }^{2}$. 


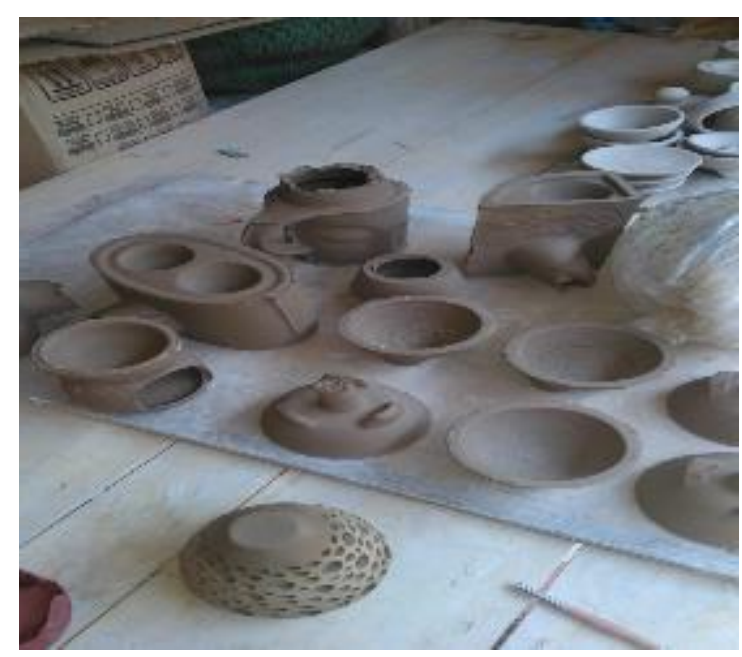

Gambar 2. Proses Pembuatan Kerajinan Keramik

Tabel 1. Profil Mitra

\begin{tabular}{|c|c|}
\hline Keterangan & Siku Bali Handycraft \\
\hline 1) Nama Pemilik & I Wayan Catur \\
\hline 2) Nama UMKM & Siku Bali Handycraft \\
\hline 3) Jenis Usaha & Kerajinan Keramik \\
\hline 4) Tanggal Pendirian Usaha & 14 Oktober 2009 \\
\hline 5) Alamat & $\begin{array}{l}\text { Banjar Biya Desa Keramas Kecamatan } \\
\text { Blahbatuh Gianyar }\end{array}$ \\
\hline 6) Rata-rata penjualan/bulan & unit \\
\hline 7) Rata-rata pendapatan/bulan & 20.000 .000 \\
\hline 8) Rata-rata produksi/bulan & Unit \\
\hline 9) Pangsa Pasar & Lokal dan Nasional \\
\hline 10) Jumlah Tenaga Kerja & 4 Orang \\
\hline
\end{tabular}

Harga jual 1 buah kerajinan keramik berkisar antara Rp. 10.000 sampai dengan Rp. 150.000.Pengelolaan "Siku Bali handycraft" belum dilakukan secara baik, dalam arti masih dilakukan secara konvensional. Pembukuan keuangan belum dimiliki sehingga pemilik/pengrajin tidak mengetahui secara akurat besaran keuntungan yang didapatkan dan besaran biaya yang dihabiskan dalam proses produksi dan operasional. Tenaga kerja yang dimiliki oleh bapak I Wayan Catur sebanyak 4 orang yang berasal dari daerah tersebut. Pola pemasaran "Siku Bali Handycraft" belum optimal karena pemiliknya memiliki keterbatasan kemampuan dan pemahaman dalam mengoperasikan produknya secara online. Tempat produksi dan showroom dari "Siku Bali Handycraft" masih dilakukan di rumah pemiliknya sehingga terkesan cukup sempit dan kurang nyaman bagi pelanggan yang ingin melihat pajangan kerajinan keramik yang dimilikinya. 

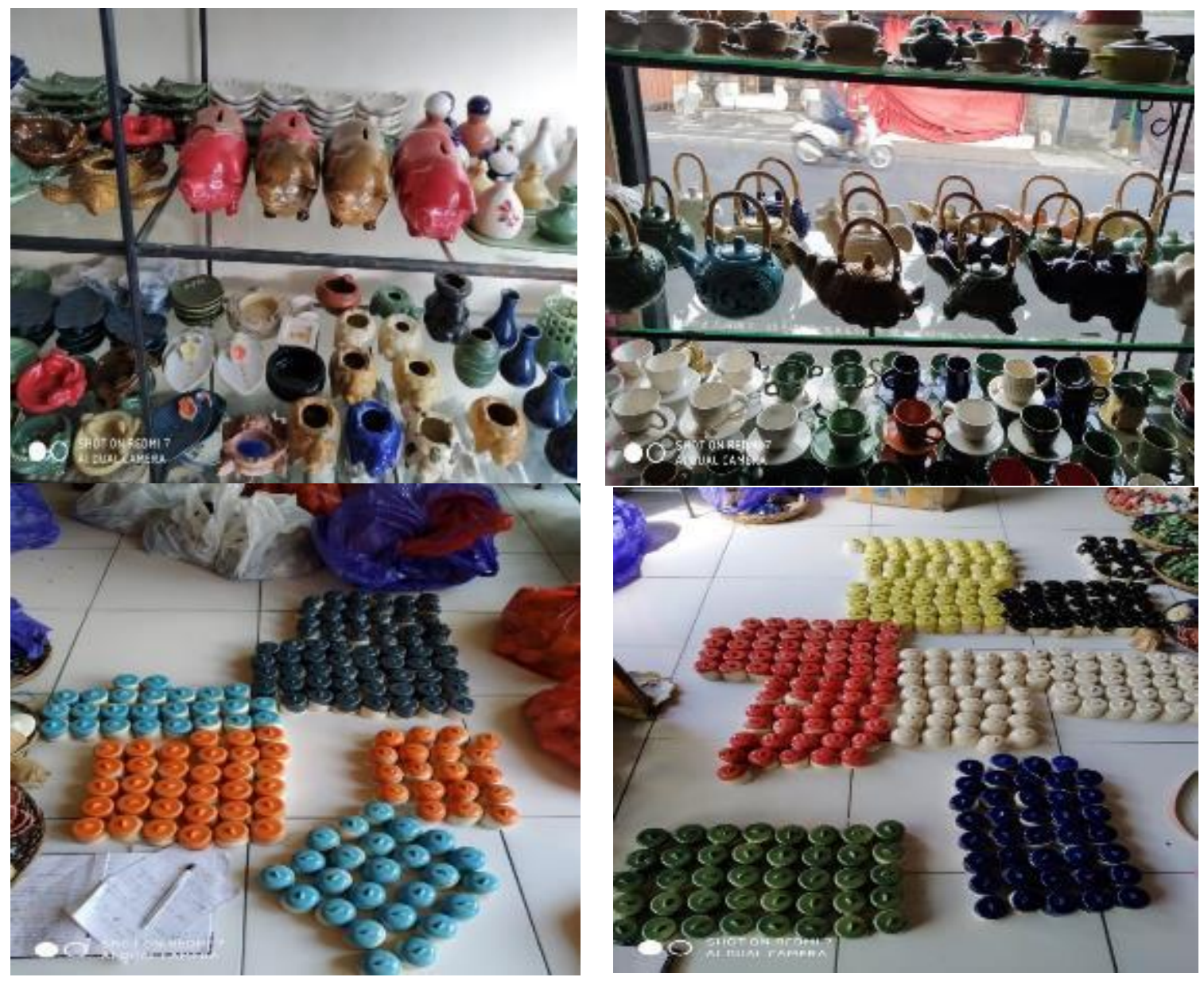

(C) 2020 Jurnal Abdi Masyarakat Universitas Kadiri | 5 

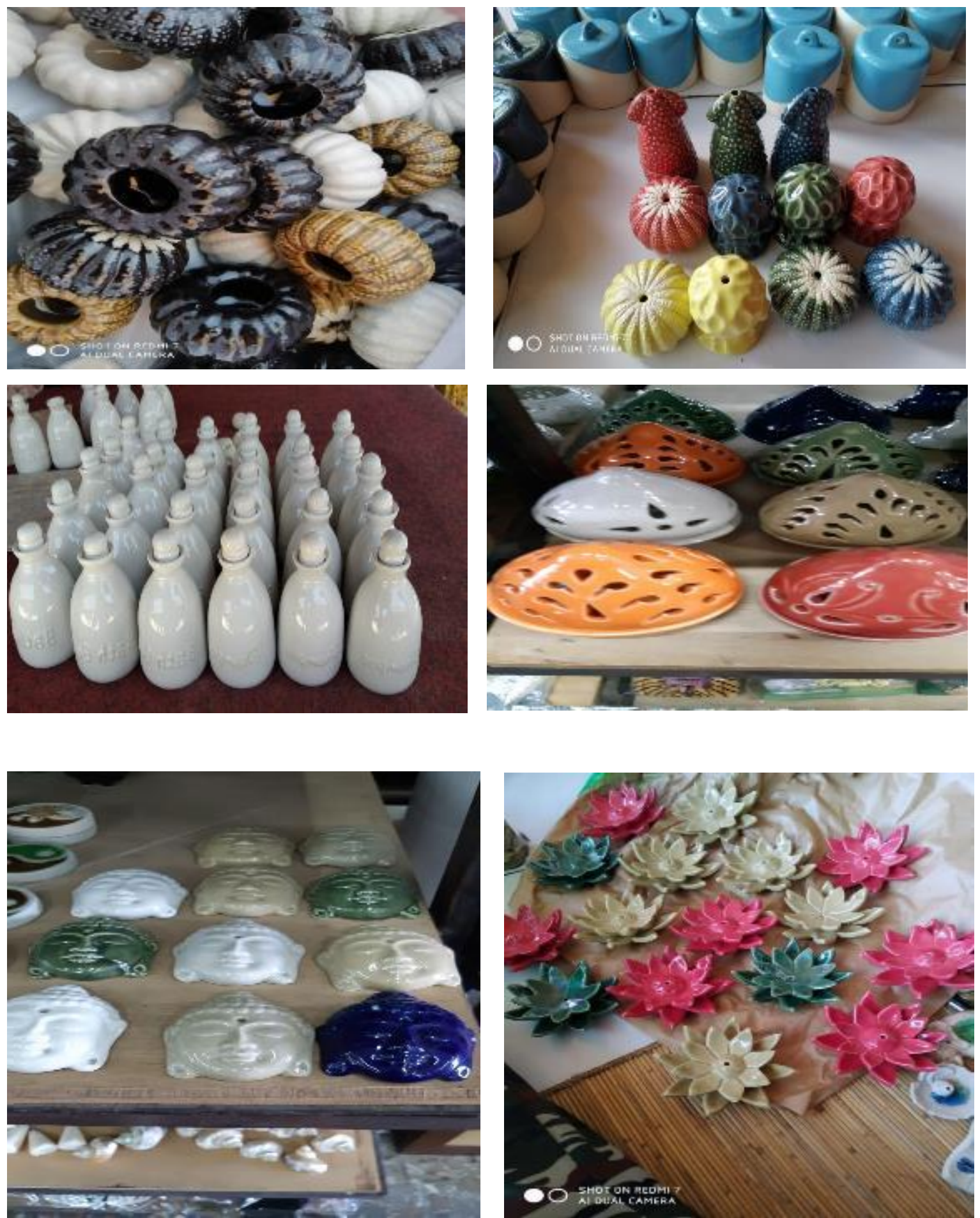

Gambar 3. Berbagai Jenis Kerajinan Keramik Karya I Wayan Catur

(C) 2020 Jurnal Abdi Masyarakat Universitas Kadiri | 6 
Berkaitan dengan pengelolaan manajemen mitra, maka dapat dideskripsikan kondisi mitra tersebut:

1) Belum memiliki pembukuan untuk menghitung laba rugi, harga pokok produksi dan pencatatan asset yang dimilki.

2) Belum memiliki SOP, baik terkait bahan baku (tanah liat) maupun alur di dalam proses produksinya.

3) Pemasaran dilakukan belum optimal sehingga masih banyak yang belum mengetahui jelas produksinya,

4) Belum memiliki katalog produk sehingga susah didalam melakukan promosi.

\section{METODE PELAKSANAAN}

Pengabdian masyarakat Kerajinan Keramik Aneka Produk Olahan Tanah Liat Siku Bali Handycraft di Banjar Biya Desa Keramas Kecamatan Blahbatuh Gianyar ini bertujuan untuk mengatasi permasalah yang dihadapi berkaitan dengan pengembangan usahanya. Adapun solusi yang dapat ditawarkan untuk mengatasi permasalahan mitra tersebut antara lain dalam bentuk pelatihan, pelatihan yang di rencanakan sebagai berikut :

\section{Pembuatan Buku Laporan Keuangan Sederhana}

Pelaksanaan program ini dilakukan melalui pendekatan individual. Pendekatan individual ini diawali dengan menggali pemahaman mitra berkaitan dengan pembukuan. Setelah menggali pemahaman mitra mengenai pembukuan, kemudian dilanjutkan dengan memberikan materi dan pemahaman seperti apa bentuk dari buku keuangan sederhana serta apa saja isi dari buku keuangan sederhana. Kemudian, mitra diajak mencari tahu hal apa saja yang dibutuhkan jika ingin mengetahui berapa laba bersih yang dihasilkan dan berapa besar riilnya biaya yang dihabiskan serta membuat buku laporan keuangan sederhana. Setelah memberikan pemahaman, mitra kemudian diberikan sebuah buku kosong untuk diajak menyusun buku laporan keuangan sederhana.

Pendekatan ini menekankan para mitra untuk dapat membuat sebuah buku laporan keuangam sederhana. Mitra di dampingi oleh tim pengusul (ketua pengusul) untuk menyusun buku laporan keuangan sederhana. Mitra akan dibimbing dan didampingi untuk mencatat setiap hal yang berkaitan dengan pengeluaran biaya dan pemasukan dalam proses produksi dan pemasaran kerajinan keramik termasuk besarnya upah yang harus dibayarkan 
kepada tenaga kerjanya. Mitra diharapkan nantinya dapat membuat laporan keuangan sederhana, dapat mengetahui berapa besarnya biaya yang dihabiskan dalam proses pembuatan kerajinan keramik, dapat menentukan harga jual dan besarnya upah yang harus dibayarkan kepada tenaga kerjanya. Dengan pemahaman yang diberikan diharapkan nantinya kelangsungan usaha mitra dapat berjalan lancar dan berkembang.

\section{Pelatihan Akuntansi Manajemen}

Selain mengetahui tentang buku laporan keuangan sederhana yang merupakan salah satu bagian dari akuntansi keuangan, mitra juga akan diberikan pemahaman tentang akuntansi manajemen, dimana akuntansi manajemen akan memberikan dasar pembuatan keputusan bisnis sehingga mitra bisa lebih siap untuk mengelola dan melakukan fungsi pengontrolan dalam menjalankan aktifitas bisnisnya.

Mitra pada nantinya diharapkan dapat mengetahui rincian biaya produksi, harga pokok, biaya overhead yang dapat dibayarkan untuk menunjang kegiatan operasional dalam aktifitas bisnisnya. Sehingga dengan adanya pemahaman tentang akuntansi manajemen mitra dapat merencanakan, mengevaluasi, dan mengendalikan kegiatan operasionalnya, serta untuk mengukur akuntabilitas penggunaan sumber daya yang digunakan.

\section{Pelatihan Penyusunan SOP Terkait Bahan Baku (Tanah Liat) Dan Alur Proses Produksi}

Mitra belum memahami SOP terkait alur proses produksi dari tanah liat menjadi kerajinan keramik. Untuk mengatasi permasalahan tersebut, tim pengusul (anggota) akan membantu dalam memberikan penyuluhan tentang penyusunan SOP terkait alur proses produksi dari tanah liat menjadi kerajinan keramik. Tim pengusul (anggota) akan memberikan penjelasan dan pendampingan dalam membuat SOP sehingga pengelolaan SDM dalam usaha mitra terlihat jelas dimana pembagian pekerjaan jelas antara satu dengan yang lainnya dan tidak adanya tumpang tindih pekerjaan satu dengan lainnya. Dengan adanya bantuan ini diharapkan nantinya mitra dapat menerapkan strategi yang tepat untuk usahanya sehingga usahanya dapat berkembang dan hasilnya lebih maksimal lagi.

\section{Pembuatan Katalog Produk}

Mitra belum memiliki katalog produk. Katalog produk berisi lengkap mengenai produk olahan kerajinan keramik yang dimiliki “Siku Bali Handycraft”. Pembuatan katalog 
produk dilakukan oleh tim pengusul (anggota) sehingga produk-produk yang dimiliki Siku Bali Handycraft lebih jelas dan lebih mudah untuk dipasarkan, baik secara langsung maupun secara online.

\section{Pelatihan Dalam Membuat Sistem Pemasaran Produk Secara Online dan Pengoperasiannya}

Membantu mitra dalam memasarkan hasil produksinya, dimana selama ini mitra hanya mengandalkan pelanggan tetapnya saja dalam memasarkan hasil produksinya. Berdasarkan pendekatan individual yang dilakukan diketahui bahwa mitra merupakan orang yang tidak paham tentang teknologi informasi serta tidak tahu bagaimana cara memanfaatkan teknologi informasi tersebut. Oleh karena itu tim pengusul (anggota) akan memberikan pelatihan tentang strategi pemasaran, membantu dalam membuatkan akun sosial media seperti facebook dan instagram serta melakukan pendampingan dalam penggunaannya. Diharapkan nantinya dengan penggunaan sosial media tersebut mitra dapat memperluas pemasaran produknya.

\section{HASIL DAN PEMBAHASAN}

Berdasarkan permasalahan yang telah disampaikan sebelumnya pada mitra, maka hal-hal yang akan dilakukan selama kegiatan meliputi:

1. Memberikan pendampingan dan konsultasi mengenai pembuatan sistem pembukuan yang meliputi buku harian, laba rugi, neraca, perhitungan harga pokok produksi. Hal ini dilakukan dengan harapan mitra memiliki gambaran yang jelas tentang hasil operasionalnya dan mengetahui harga dasar dari produksinya sehingga memudahkan didalam mengambil keputusan terkait operasional dan pengembangan usaha dimasa depan.

2. Pendampingan dalam penyusunan SOP terkait bahan baku (tanah liat) dan alur proses produksi, sehingga diharapkan standar bahan baku yang dibeli sesuai dengan telah ditentukan dan masing-masing tenaga kerja dapat melakukan proses produksi sesuai dengan alurnya untuk menghindari tumpang tindih pekerjaan.

3. Pembuatan katalog produk

4. Pembuatan sarana promosi melalui online sehingga diharapkan dapat menunjang pemasaran produk dari mitra. 
5. Pendampingan dan pelatihan didalam mengoperasikan dan melakukan update terhadap pemasaran secara online yang dimiliki sehingga diharapkan informasi terbaru tentang produk dan perusahaan bisa disampaikan.

Berikut ini capaian pelaksanaan kegiatan sesuai dengan yang diprioritaskan pada masingmasing mitra, yaitu:

1) Pemberian pendampingan dan pelatihan pembukuan sederhana, menjelaskan pencatatan sederhana harian, mingguan sampai bulanan. Bagaimana cara mencatat biaya - biaya produksi dan mencatat penjualan. Memisahkan keuangan pribadi dengan keuangan hasil usaha, sehingga dapat melihat keuntungan usaha secara jelas dan diharapkan nantinya dapat menyisihkan laba untuk investasi.

2) Pendampingan dan memberikan pelatihan akuntansi manajemen, dimana mitra dijelaskan mengenai rincian biaya produksi, harga pokok, biaya overhead yang dapat dibayarkan untuk menunjang kegiatan operasional dalam aktifitas bisnisnya.

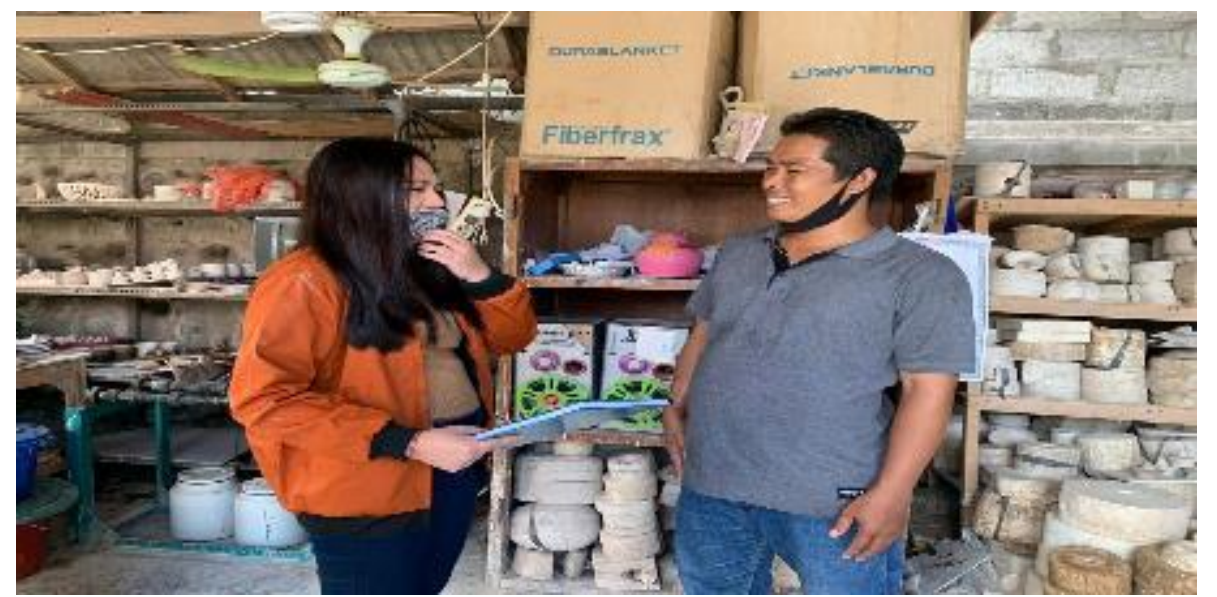

\section{Gambar 4. Pendampingan Pelatihan Pembukuan dan Akuntansi Manajemen}

3) Pendampingan dalam penyusunan SOP terkait bahan baku (tanah liat) dan alur proses produksi, sehingga diharapkan standar bahan baku yang dibeli sesuai dengan telah ditentukan dan masing-masing tenaga kerja dapat melakukan proses produksi sesuai dengan alurnya untuk menghindari tumpang tindih pekerjaan.

4) Pembuatan katalog produk sehingga Mitra mempunyai katalog yang berisi lengkap mengenai produk olahan kerajinan keramik "Siku Bali Handycraft" 
5) Membantu mitra dalam pembuatan sosial media yang dapat membantu dalam proses pemasaran produk dan memperkenalkan produk bukan hanya ke konsumen lokal Bali saja tapi kepada konsumen luar Bali seperti Instagram serta pendampingan dan pelatihan didalam mengoperasikan dan melakukan update terhadap pemasaran secara online yang dimiliki sehingga diharapkan informasi terbaru tentang produk dan usaha bisa disampaikan.

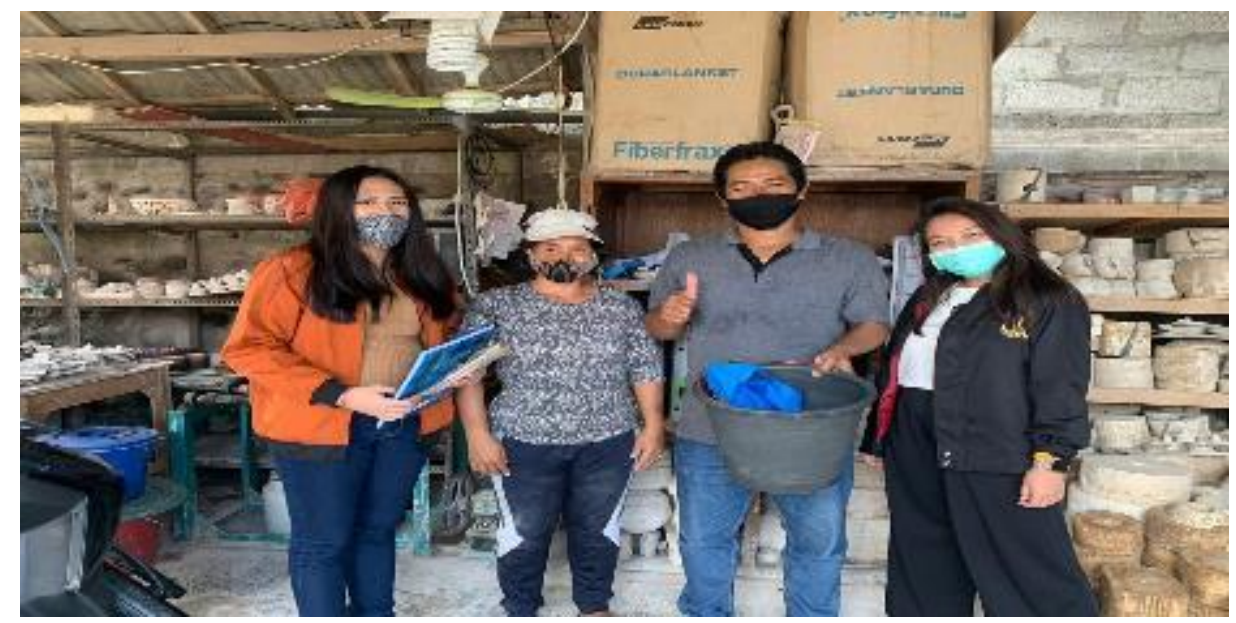

Gambar 5. Pembuatan Sosial Media dan Pelatihan Pengoperasiannya Secara Online

6) Melakukan pengadaan/pembelian kuas dengan berbagai ukuran. Kuas ini dapat dipergunakan untuk membantu mitra dalam pewarnaan keramik.

7) Melakukan pengadaan/pembelian alat pahat dengan berbagai ukuran. Alat pahat ini dapat dipergunakan untuk membantu mitra dalam membuat ukiran dalam keramik.

8) Melakukan pengadaan/pembelian kayu giling. Kayu giling ini dapat dipergunakan untuk membantu mitra dalam menggilas tanah liat agar mampat dan memiliki konsistensi atau susunan pembentuk yang seragam.

9) Melakukan pengadaan/pembelian beberapa ember. Ember ini dapat dipergunakan untuk membantu mitra dalam proses pewarnaan glasir.

10) Melakukan pengadaan/pembelian sekop. Sekop ini dapat dipergunakan untuk membantu mitra dalam proses pengambilan tanah liat. 


\section{KESIMPULAN DAN SARAN}

\section{Kesimpulan}

Berdasarkan atas kegiatan yang telah dilaksanakan, dapat disimpulkan bahwa permasalahan yang dihadapi oleh mitra meliputi: 1) Belum memiliki pembukuan untuk menghitung laba rugi, harga pokok produksi dan pencatatan asset yang dimilki. 2) Belum memiliki SOP, baik terkait bahan baku (tanah liat) maupun alur di dalam proses produksinya. 3) Pemasaran dilakukan belum optimal sehingga masih banyak yang belum mengetahui jelas produksinya. 4) Belum memiliki katalog produk sehingga susah didalam melakukan promosi. Capaian pelaksanaan kegiatan untuk mengatasi permasalah tersebut meliputi : 1) Pembentukan dan perancangan system pembukuan baik laba rugi dan harga pokok produksi, 2) Penyusunan SOP dalam pembelian bahan baku (tanah liat) dan alur proses produksi. 3) Pembuatan katalog produk-produk yang dimiliki. 4) Pembuatan strategi promosi / pemasaran melalui online.

\section{Saran}

Berdasarkan pelaksanaan kegiatan yang sudah dilakukan, maka mitra hendaknya terus menjaga konsistensi dari sisi produksi, pemasaran dan keuangan sehingga keberlangsungan hidup usahanya dapat terjamin. Selain dari sisi produksi, pemasaran dan keuangan, usaha mitra juga perlu diberikan penyuluhan dari segi aspek hukum terutama mengenai ijin usaha dan paten produk.

\section{UCAPAN TERIMAKASIH}

Ucapan terimakasih saya sampaikan kepada Lembaga Pengabdian Masyarakat Universitas Warmadewa yang telah memberikan bantuan dana hibah Pengabdian kepada Masyarakat ini. 